\title{
Оцінка динаміки рецидивів у хворих на туберкульоз легень в Україні
}

Мельник В.М., Матусевич В.Г., Новожилова І.О., Тарасенко О.Р., Бушура І.В., Приходько А.М.

ДУ «Національний інститут фтизіатрії і пульмонології ім. Ф.Г. Яновського НАМН України», м. Київ, Україна

Епідемічна ситуація щодо туберкульозу (ТБ) в Україні, як і у світі, залишається напруженою: показники захворюваності та смертності не досягають цільових згідно зі Стратегією Всесвітньої організації охорони здоров'я (ВОО3) «Покласти край ТБ». За період 2012-2019 рр. в Україні захворюваність на всі форми вперше виявленого ТБ (нові випадки + рецидиви) зменшилася із 72,1 до 60,1 на 100 тис. населення, смертність - із 15,1 до 8,8 на 100 тис. населення. В офіційній статистичній звітності захворюваність на рецидиви ТБ (РТБ) подається разом із випадками вперше діагностованого ТБ: у такий спосіб від широкого кола громадськості приховують частоту РТБ, що свідчить про хиби лікування хворих. Ефективність терапії РТБ, за даними когортного аналізу, становила 65,1 \% у 2015 р. та 68,4 \% у 2019 р. (згідно з рекомендаціями ВООЗ виявлення хворих має наближатися до 70,0%, а ефективність лікування - до 85,0 \%). На тлі низької ефективності лікування відзначається й недостатнє виявлення хворих на ТБ, що має дуже незначну тенденцію до збільшення з 58,9 \% за мазком у 2016 р. до 59,4 \% у 2019 р. Ці статистичні дані підтверджують потребу у вивченні ситуації з РТБ і розробленні запобіжних заходів. За даними лабораторної діагностики рецидивів та інших випадків повторного лікування ТБ, частка випадків мультирезистентного ТБ становила 46,4 \% у 2018 р та 42,9 \% у 2019 р. Захворюваність на РТБ у 2012, 2016, 2017 рр. була майже на однаковому рівні: 12,4; 12,9; 12,1 на 100 тис. населення відповідно. Лише у 2018 р. вона зменшилася до 11,1 на 100 тис., але це теж $є$ високим показником. Характерно, що виявлення хворих на РТБ разом з іншими випадками повторного лікування ТБ за допомогою методу бактеріоскопії мазка коливається від 49,1 \% у 2012 р. до 60,8 \% у 2018 р. та 59,4 \% у 2019 р. Але відзначається зростання частки виявлення хворих на РТБ за мазком та/або культурою - із 78,8 \% у 2017 р. до 81,4 \% у 2019 р. Це свідчить про поліпшення бактеріологічної діагностики РТБ і водночас про збільшення кількості клінічно тяжких хворих на ТБ. Отже, характеристика РТБ $є$ своєрідним дзеркалом, яке відображає слабкі ланки в проведенні протитуберкульозних заходів, тому істинні РТБ нерідко реєструють як випадки вперше діагностованого ТБ. Саме когорта хворих на РТБ підтримує високі показники захворюваності на ТБ легень і смертності від нього. Досі немає систематизованого погляду на причини РТБ і, відповідно, чітких запобіжних заходів. Цій проблемі приділяється недостатньо уваги в протитуберкульозних закладах України. 